\title{
Synthesis, Characterization, Antimicrobial, DNA cleavage, and Cytotoxicity Studies of Some Metal (II) Complexes of Tridentate Schiff Base Ligand: 2-hydroxy-3-((4-(4-phenylthiazol-2-yl) semicarbazide) methyl) Benzoic Acid
}

\author{
Shambuling Karabasannavar ${ }^{1}$, Parvati R Allolli ${ }^{2}$, Basavaraj M. Kalshetty ${ }^{3}$ \\ ${ }^{1}$ Research \& Department centre, Bharathiar University, Coimbatore. Tamilnadu, INDIA. \\ ${ }^{2}$ Department of Pharmaceutical Chemistry, Karnataka State Women University, Bijapur. Karnataka, INDIA. \\ ${ }^{3}$ Department of chemistry, BLDE's Science College Jamkhandi, Bagalkot, Karnataka, INDIA.
}

\begin{abstract}
Objective: The main aim of the present work was to synthesize a novel Schiff base ligand 2-hydroxy-3-((4-(4-phenylthiazol-2-yl) semicarbazide) methyl) benzoic acid is obtained by the condensation of $\mathrm{N}$-(4-phenylthiazole-2-yl) hydrazine carboxamide with 3-Aldehydosalicylic acid and its $\mathrm{Cu}(\mathrm{II}), \mathrm{Co}(\mathrm{II}), \mathrm{Ni}(\mathrm{II})$, and $\mathrm{Zn}$ (II) complexes and study of their biological activity. Methods: The compounds are characterized by elemental analysis and various physicochemical techniques like IR, H NMR, ESI-mass, and molar conductance data. All the compounds were screened for their antibacterial and antifungal activity by MIC method. Further, to study the in vitro cytotoxicity properties of all the compounds against Artemia salina and DNA cleavage activity by Agarose Gel Electrophoresis (AGE) method. Results: Spectral investigations suggested square pyramidal coordination geometrical arrangement for all the metal (II) complexes, having 1:1 stoichiometric ratio of the type $\left[\mathrm{ML}(\mathrm{Cl})_{2}\right]$. The antimicrobial activity results revealed that the metal complexes were found to be more active than the free ligand. Furthermore, the DNA cleavage activity of the compounds on plasmid DNA pBR322 molecule showed moderate activity. Conclusion: The newly synthesized ligand acts as OON donor tridentate chelate and coordinated through an oxygen of azomethine nitrogen, Phenolic $\mathrm{OH}$ and Carboxylic acid $(\mathrm{COOH})$ of 3-Aldehydosalicylic acid to the $\mathrm{Cu}, \mathrm{Co}, \mathrm{Ni}$ and $\mathrm{Zn}$ metal ions and form square pyramidal geometrical arrangement. All the complexes are found to be non-electrolytic in nature. Further, all the newly prepared compounds showed moderate biological activity.
\end{abstract}

Key words: Transition metal complexes, Thaizole, Schiff base, Antimicrobial, DNA cleavage.

\section{INTRODUCTION}

Medicinal chemistry has generated important interest in the design of metal complexes as potential diagnostic and therapeutic agents. Thiazoles are one of the most intensively investigated classes of aromatic five-membered heterocyclic and containing three carbons, one sulphur, and one nitrogen atom. Thiazole and its derivatives are very useful compounds in different fields of chemistry including medicine and agriculture. Many thiazole derivates such as bleomycin, abafungin, ritonavir, and sulfathiazole are well known potential biologically active compounds. ${ }^{1}$ Also, thiazoles are the starting material for several compounds including dyes, fungicides, sulphur drugs, biocides and chemical reaction accelerators which exhibit microbial activity that can be well characterized by a large number of drugs in the market containing this moiety. ${ }^{2}$ Schiff
Submission Date: 10-04-2017; Revision Date: 13-07-2017; Accepted Date: 15-07-2017.

DOI: 10.5530/ijper.51.4.109 Correspondence: Basavaraj M. Kalshetty, Department of chemistry, BLDE's Science College Jamkhandi, Bagalkot, Karnataka, INDIA. Tel: +91-8353-220003; Fax: +91- 8353-220183 E-mail: drkalshetty@gmail. com

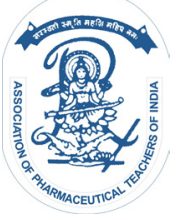

www.ijper.org 
base complexes of transition metals are particular attention to inorganic chemists because of their structural, chemical and spectral properties are more strongly dependent on the nature of the ligand structure. ${ }^{3-6}$ The coordination chemistry of transition metal complexes derived from Schiff base ligands have been among the majority widely studied coordination compounds in current years. ${ }^{78}$ Since they are becoming increasingly important as analytical, biochemical and antimicrobial reagents and Metal complexes of $\mathrm{O}, \mathrm{S}$, and $\mathrm{N}$-chelating ligands have more attracted considerable attention because of their interesting Physico-chemical properties, strong biological activities. ${ }^{9-12}$ The fact, copper, calcium, magnesium, zinc, iron, chromium, molybdenum, and vanadium are fundamental metallic elements and exhibit great biological activity when associated with certain metal-protein complexes, participating in oxygen transport the storage of ions or electronic transfer reactions, ${ }^{13,14}$ has created enormous interest in the study of systems containing theses metals. ${ }^{15}$ Thiazole ring finds applications such as liquid crystals, fluorescent dyes, polymers, insecticides and antioxidants. ${ }^{16,17}$ Therefore it has been found interesting to study the metal complexes containing thiazole moiety. Some of Schiff bases and their transition metal complexes have also been used as drugs as fungicidal, bactericidal, anti-tubercular and antiviral agent. ${ }^{18,19}$ In current years, metal-based drugs have gained much importance in the medicinal field. They are used as medicines for the treatment of cancer, diabetes, cardiovascular diseases and anti-inflammatory. ${ }^{20-22}$ The medical application of the metal complexes compounds of thiazole to impart strength, elasticity, and impermeability of water. ${ }^{23}$ Analogous of hetero-aromatic Schiff base derived from 3 -aldehydosalicylic acid have been to possess biological activity. Azomethine group ( $=\mathrm{C}=\mathrm{N}-$ ) which is formed by the condensation of primary amines with aromatic aldehydes. Such Schiff base ligands containing various donor atoms like $\mathrm{O}, \mathrm{N}$, and $\mathrm{S}$ showed broad biological activities and they are bond to the metal ions of $\mathrm{Cu}$ (II), Ni (II), Zn (II), Co (II). ${ }^{24-26}$ Based on these findings and in continuation of our research work on coordination chemistry, we have synthesized the new Schiff base ligand 2-hydroxy-3-((4-(4-phenylthiazol-2-yl) semicarbazide) methyl) benzoic acid containing the carbonyl, azomethine, and hydroxyl groups as potent chelating sites. In order to study the ligation behavior of this ligand, we have prepared a series of its $\mathrm{Cu}(\mathrm{II}), \mathrm{Co}(\mathrm{II})$, $\mathrm{Ni}(\mathrm{II})$ and $\mathrm{Zn}$ (II) complexes and characterized them by various physicochemical techniques and studied their antimicrobial, DNA cleavage and In vitro Cytotoxicity.

\section{Experimental}

\section{Analysis and physical measurement}

Elemental analysis $(\mathrm{C}, \mathrm{H}$, and $\mathrm{N})$ was performed on Vario EL CHNS analyzer. IR spectra of the synthesized Schiff base and its metal complexes were recorded in $\mathrm{KBr}$ pellets on a Parkin-Elmer FT-IR instrumental in the range $4000-250 \mathrm{Cm}^{-1} .{ }^{1} \mathrm{HNMR}$ spectra of ligand and its $\mathrm{Zn}$ (II) complex were recorded on the FT-NMR spectrometer model Bruker Avance II, $400 \mathrm{MHz}$ using $\mathrm{d}_{6}$ DMSO as solvent. ESI-MS were recorded on a mass spectrometer equipped with electrospary ionization (ESI) source having mass arranged of $4000 \mathrm{amu}$ in quadruple and $20000 \mathrm{amu}$ in Tof. Molar conductivity measurement were recorded on ELICO (CM-180) conductivity bridge in DMF $\left(10^{-3}\right)$ solution using a diptype conductivity cell fitted with a platinum electrode.

\section{Material and methods}

All reagents and chemicals required were AR grade, purchased commercially. All the solvents were purified by distillation and used. Thiourea, bromine, acetophenone, salicylic acid, hexamethylenetetramine, benzene, ammonium hydroxide, barium chloride, sodium hydroxide, hydrochloric acid and pyridine were purchased from S.D. Fine Chemicals, ethylchloroformate and hydrazine hydrate were purchased from Sigma Aldrich chemical company, India. Melting points of the newly synthesized compounds were determined by electro-thermal apparatus using open capillaries and are uncorrected. The metal and chloride contents of the metal complexes were determined as per standard procedures. ${ }^{27}$ Purity of the compounds was checked by TLC and the spots were observed in iodine vapour. The precursor $\mathrm{N}$-(4-phenylthiazol-2-yl) hydrazinecarboxamide was prepared by the literature method. ${ }^{28}$

\section{Synthesis of Schiff base ligand (L)}

An equimolar mixture of $\mathrm{N}$-(4-phenylthiazol-2-yl) hydrazinecarboxamide $(0.001 \mathrm{~mol})$ and 3-Aldehydosalicylic acid $(0.001 \mathrm{~mol})$ in ethanol $(30 \mathrm{ml})$ was refluxed with a catalytic amount of glacial acetic (1-2 drops) for about 5-6 hrs on a water bath, the yellow colored product which separated in hot was filtered off, washed with hot ethanol, dried and recrystallized from alcohol (Scheme 1). The reaction was monitored by TLC. Yield: $72 \%$ M.P: $267-280^{\circ} \mathrm{C}$.

\section{Synthesis of metal (II) complexes}

To the 2-hydroxy-3-((4-(4-phenylthaizole-2-yl) semicarbazido) methyl) benzoic acid $(0.001 \mathrm{~mol})$ in ethanol $(25 \mathrm{ml})$ was added hot ethanolic solution $(20 \mathrm{ml})$ of respective metal chlorides $(0.001 \mathrm{~mol})$. The reaction 


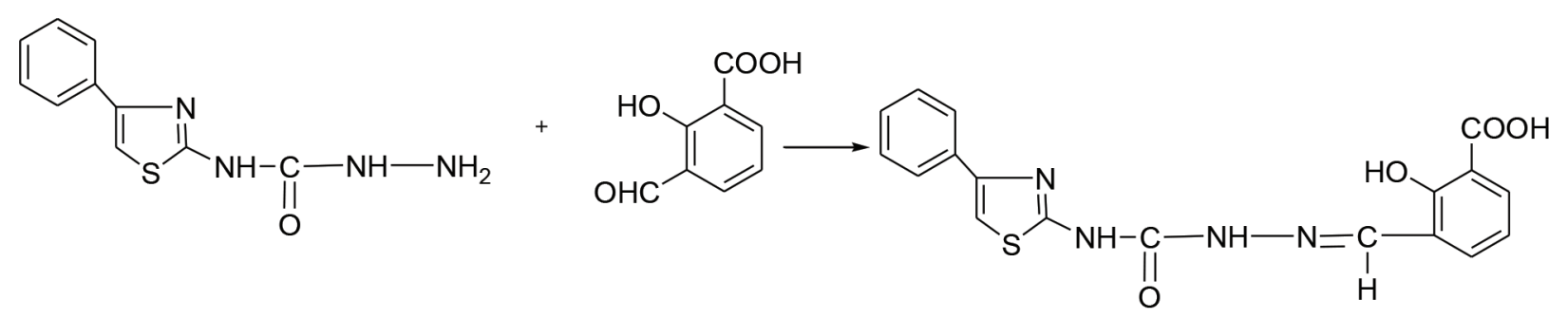

2-hydroxy-3-((4-(4-phenylthiazol-2-yl)semicarbazido)methyl)benzoic acid

Scheme 1: Symthesis of Schiff Base Ligand $(L)$

Scheme 1: Synthesis of Schiff base ligand (L).

mixture was then refluxed on water bath for about 4-5 hrs, $\mathrm{pH}$ of the reaction mixture adjusted $\mathrm{Ca} .7$ to 7.5 by adding alcoholic solution of sodium acetate $(0.5 \mathrm{gm})$ and refluxing continued for about an one hr more. The reaction mixture was cooled to room temperature and poured into distilled water. The colored solids separated were collected by filtration, washed with sufficient quantity of distilled water, then with hot ethanol to remove any traces of unreacted starting materials and finally dried in a vacuum over anhydrous calcium chloride in desiccator.

\section{Biological activities \\ Antimicrobial assays}

The biological activities of the newly synthesized ligand and their $\mathrm{Cu}$ (II), $\mathrm{Co}$ (II), $\mathrm{Ni}$ (II) and $\mathrm{Zn}$ (II) complexes were screened for their antibacterial and antifungal activities by disc and well diffusion method respectively. ${ }^{29}$

The in vitro antibacterial activities of the compounds were tested against two Gram-negative [Escherichia coli and Salmonella typhi] and two Gram-positive [Bacillus subtilis and Staphylococcus aureus] bacteria. The in vitro antifungal activities were carried out against Candida albicans, Cladosporium oxy-sporum and Aspergillus Niger fungi. The stock solutions of the test chemicals $\left(1 \mathrm{mg} \mathrm{mL}^{-1}\right)$ were prepared by dissolving $10 \mathrm{mg}$ of the each test compound in $10 \mathrm{~mL}$ of freshly distilled DMSO. The different concentrations of the test compounds (100, 50,25 and $12.5 \mu \mathrm{gL}^{-1}$ ), were prepared by diluting the stock solution with the required amount of distilled DMSO. The lowest concentration that inhibited microbial growth was called as the MIC value. Further the dilutions for the metal chlorides were prepared by using distilled water and control experiments were carried out by using DMSO solvent alone.

\section{Antibacterial screening}

Muller-Hinton agar media was used for the antibacterial studies. The pure dehydrated Muller-Hilton agar (38 g) was dissolved in $1000 \mathrm{~mL}$ distilled water. The pure cultures of the bacterial strains E. coli, S. aureus, B. subtilis and S. typhi were sub cultured by inoculating them in the nutrient broth and they were incubated at $37^{\circ} \mathrm{C}$ for about $18 \mathrm{~h}$. The agar plates were prepared by using the above media. Each plate were inoculated with $18 \mathrm{~h}$ old bacterial culture $(100 \mu \mathrm{L})$ using a micropipette and spread uniformly using bent glass rod. Wells were dug with the help of $6 \mathrm{~mm}$ sterile metallic cork borer. The drug gentamycin is used as standard. Different concentration of the test compounds and their respective metal chloride solutions were incorporated into the wells using micropipette and the plates were kept for incubation at $37^{\circ} \mathrm{C}$ for $24 \mathrm{~h}$. Soon after the completion of incubation period, the diameter of the inhibition zone generated by each test compound against bacterial growth were measured using antibiogram zone measuring scale.

\section{Antifungal screening}

Potato dextrose agar (PDA) media was used for the antifungal studies. The following ingredients were used to prepare the media i.e. potatoes (sliced washed unpeeled) $200 \mathrm{~g}$, dextrose $20 \mathrm{~g}$, agar $20 \mathrm{~g}$ in $1000 \mathrm{~mL}$ distilled water. The pure cultures C. albicans, C. oxysporum and A. niger were inoculated on PDA slants. These slants were incubated at $32^{\circ} \mathrm{C}$ for 7 days. To these 7 days old slants of fungal strains, $10 \mathrm{~mL}$ of $0.1 \%$ tween- 80 solution was added and the culture were scraped with sterile inoculating loop to get uniform spore suspension. The agar plates were prepared by using the above potato dextrose agar media. Each plate were inoculated with 7 days old spore suspension of each fungal culture $(100 \mu \mathrm{L})$ using a micropipette and spreaded uniformly using bent glass rod. Wells were dug with the help of $6 \mathrm{~mm}$ sterile metallic cork borer. Each well was incorporated with the test compound solution of different concentrations and their respective metal chloride solution. The drug Fluconazole is used as standard. All the inoculated plates were incubated at $32{ }^{\circ} \mathrm{C}$ for about $48 \mathrm{~h}$. Soon after the completion of incubation period the diameter of the inhibition zone generated by each 
test compound against fungal growth were measured using antibiogram zone measuring scale.

\section{DNA cleavage experiment}

The extent to which the newly synthesized ligands and their metal complexes could function as DNA cleavage agents was examined using supercoiled plasmid $D N A$ pBR 322 (Bangal re Genei, Bengaluru, Cat. No.105850) as a target molecule. The electrophoresis method was employed to study the efficiency of cleavage by the synthesized compounds. Each test compounds $(100 \mu \mathrm{g})$ were added separately to the $225 \mathrm{mg} p B \mathrm{R} 322 \mathrm{DNA}$ sample and these samples mixtures were incubated at $37{ }^{\circ} \mathrm{C}$ for $2 \mathrm{~h}$. The electrophoresis of the test compounds was done according to the literature method. ${ }^{30}$ Agarose $(600 \mathrm{mg})$ was dissolved in hot tris-acetateEDTA (TAE) buffer $(60 \mathrm{~mL})$ (4.84 $\mathrm{g}$ Tris base, $\mathrm{pH}-8.0$, $0.5 \mathrm{M}$ EDTA L L $^{-1}$ ) and heated to boil for few minutes. When the gel attains approximately $55{ }^{\circ} \mathrm{C}$, it was then poured into the gas cassette fitted with comb. Slowly the gel was allowed to solidify by cooling to room temperature and then carefully the comb was removed. The solidified gel was placed in the electrophoresis chamber containing TAE buffer. The DNA sample $(20 \mu \mathrm{L})$ initially treated with the test compounds were mixed with bromophenol blue dye in equimolar ratio along with standard DNA marker containing TAE buffer was loaded carefully into the wells and the constant $50 \mathrm{~V}$ of electricity was supplied for about $30 \mathrm{~min}$. Later, the gel was removed, stained with Ethidium bromide solution $\left(10 \mu \mathrm{gml}^{-1}\right)$ for $15-20 \mathrm{~min}$ and then the bands were observed and photographed under UV-illuminator.

\section{In vitro Cytotoxicity}

Brine shrimp nauplii (Artemia salina) be used in the in vitro cytotoxicity analyze, according to the protocol of Meyer et. al. ${ }^{31}$ with some modifications. This is a rapid, efficient, inexpensive test and has a good relationship with cytotoxic activity. Brine shrimp (A. salina) eggs was hatch in a shallow rectangular plastic dish $(22 \times 32 \mathrm{~cm})$ packed with artificial seawater, which was prepared with a mixture of commercial salt and double distilled water. An unequal partition was made in the plastic dish with the help of a perforated apparatus. Approximately 50 $\mathrm{mg}$ of eggs are sprinkled into the large compartment, which has darkened while the small compartments were open to ordinary light. Two days after nauplii were collected by pipette by lighted side. Samples of the test compound were prepared by dissolving $20 \mathrm{mg}$ of each compound in $2 \mathrm{ml}$ of DMSO. From the stock separate vials and the volume of each vial made up to $10 \mathrm{ml}$ with artificial sea water to obtain the desired final concentra- tions. The negative control was prepared in the same manner, omitting the sample. After two days, when shrimp larvae were ready, 10 shrimp nauplii were then placed in each vial. After 24 hrs incubation, the vials were observed using a magnifying glass, and the number of survivors in each vial was counted. Tests were performed in triplicate and the resulting data were analyzed by a Finney computer program to determine the $\mathrm{LD}_{50}$ valves. $^{32}$ The results for test compounds were compared with positive control bleomycin.

\section{Results and discussion}

The newly synthesized metal complexes are colored solids, stable at room temperature and possess high melting point $\left(>278^{\circ} \mathrm{C}\right)$. The metal complexes are insoluble in water and common organic solvents but completely soluble in DMF and DMSO. The evidence for the formation of tridentates $\mathrm{OON}$ donor nature of the Schiff base ligand (L) was confirmed by using various spectral techniques. Elemental analysis and analytical data (Table 1) agree well with the proposed composition of Schiff base ligand and its metal complexes. These data of metal complexes suggest that the metal to ligand ratio of the complexes is 1:1 stoichiometry of the type $\left[\mathrm{M}(\mathrm{L})(\mathrm{Cl})_{2}\right]$ for $\mathrm{Cu}(\mathrm{II}), \mathrm{Co}$ (II), $\mathrm{Ni}$ (II) and $\mathrm{Zn}$ (II) complexes. The measured molar conductance values of the metal complexes were too low to account for any dissociation of the complexes in DMF $\left(18-36 \mathrm{ohm}^{-1} \mathrm{~cm}^{2}\right.$ mole $\left.^{-1}\right)$, indicating their non-electrolytic behavior. ${ }^{33}$

\section{IR spectral studies}

Infrared spectra helps in getting on idea on how is the ligand coordinate to metal ion. The characteristics frequencies of the expected functional groups are depicted in Table 2. IR spectrum of the ligand showed a high intensity band at $1727 \mathrm{~cm}^{-1}$ due to carbonyl function $(\mathrm{C}=\mathrm{O})$ and two absorption bands at $3259 \mathrm{~cm}^{-1}$, $3119 \mathrm{~cm}^{-1}$ due to amide $\mathrm{NH}$ and $\mathrm{NH}$ attached to thiazole moiety respectively. A high intensity band observed at $1628 \mathrm{~cm}^{-1}$ is attributed to the azomethine $(\mathrm{C}=\mathrm{N})$ vibration. IR spectrum of Schiff base ligand showed a broad band at $3176 \mathrm{~cm}^{-1}$ and $3480 \mathrm{~cm}^{-1}$ due to phenolic $\mathrm{OH}$ and COOH respectively Figure 1.

The IR spectra of the metal complexes exhibited ligand bands with the appropriate shifts due to complex formation. In the IR spectra of all the metal complexes it was observed that, the absence of band at $3176 \mathrm{~cm}^{-1}$ and $3480 \mathrm{~cm}^{-1}$ due to phenolic $\mathrm{OH}$ and $\mathrm{COOH}$ of ligand indicates the formation of coordination bond between the metal ions. IR spectrum of the metal complexes, medium intensity weak bands at $3240-3180 \mathrm{~cm}^{-1}$ and $3104-3080 \mathrm{~cm}^{-1}$ were due to amide $\mathrm{NH}$ and $\mathrm{NH}$ 


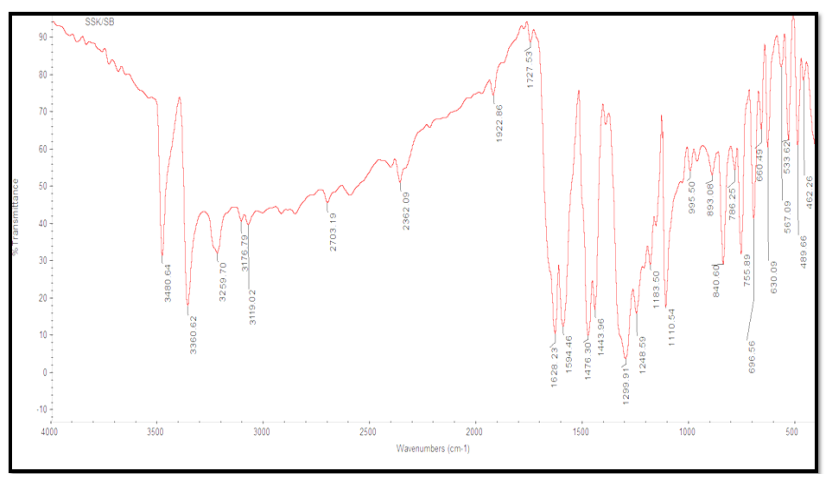

Figure 1: IR Spectrum of Schiff base ligand

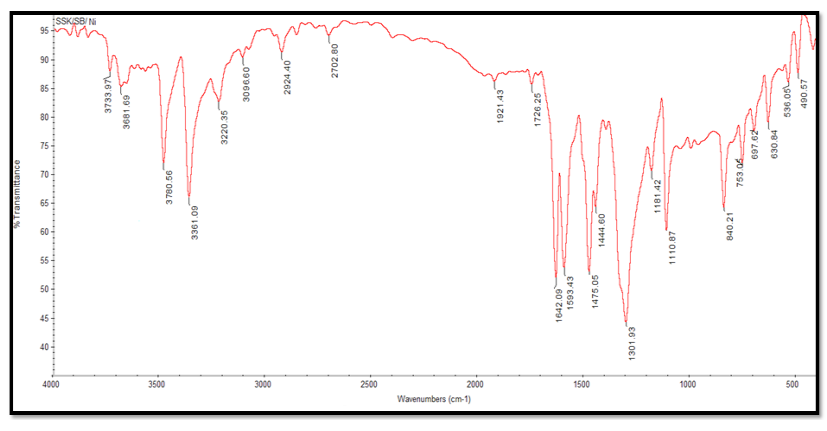

Figure 2: IR spectrum of Ni (II) complex

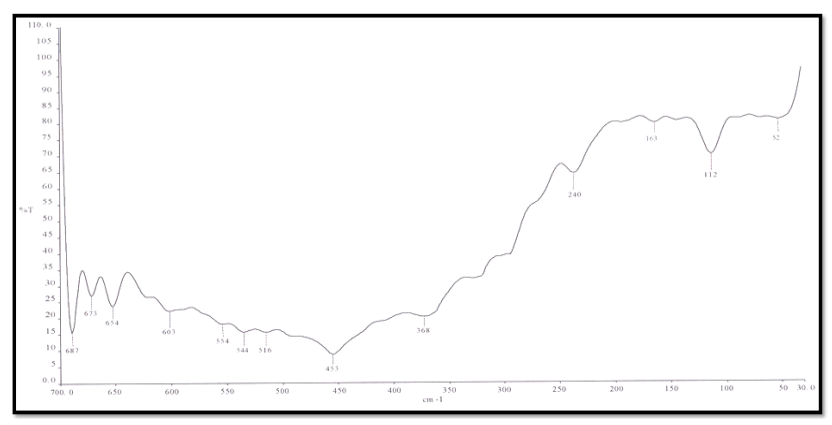

Figure 3: Far -IR spectrum of Cu (II) complex

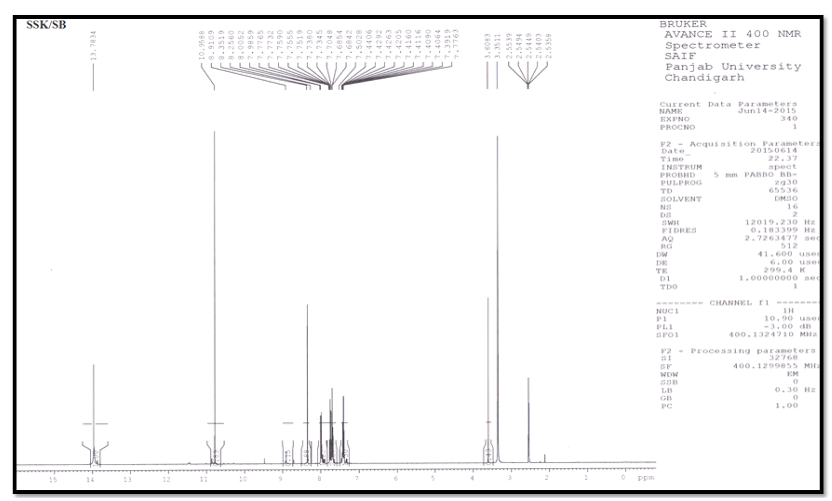

Figure 4: ${ }^{1}$ NMR spectrum of Schiff base ligand attached to thiazole moiety respectively, which appeared almost at about the same position as in the case of ligand, thus confirming their non-involvement in coordination. The IR spectrum all the complexes showed a shift of the azomethine $(\mathrm{C}=\mathrm{N})$ band towards lower frequency side about $68-26 \mathrm{~cm}^{-1}$ and appeared in the region 1594-1556 $\mathrm{cm}^{-1}$ when compared with the free ligand indicating the coordination of the azomethine nitrogen to the metal ion. ${ }^{34}$ The shift amide carbonyl $(\mathrm{C}=\mathrm{O})$ to lower frequency side which appear in the region same position as in case of ligand, thus confirming non involvement in coordination Figure 2. The formation of metal complex was further confirmed by the appearance of new bands in the region 542-514, 489-448 and $327-312 \mathrm{~cm}^{-1}$ in all the complexes due to skeletal metal-oxygen, metal-nitrogen and metal-chlorides vibrations respectively Figure 3.

\section{${ }^{1} \mathrm{H}$ NMR}

The ${ }^{1} \mathrm{H}$ NMR spectra data of Schiff base ligand (L) and its $\mathrm{Zn}$ (II) complex were recorded in d6-DMSO and depicted in Table 3. The ${ }^{1} \mathrm{H}$ NMR spectrum of ligand displayed five distinct singlet at $\delta 13.59 \mathrm{ppm}$ (s, 1H, Carboxylic acid), $\delta 12.2 \mathrm{ppm}(\mathrm{s}, 1 \mathrm{H}$, Phenolic $\mathrm{OH}), \delta 10.70$ (s,1H, CONH), $\delta 8.93$ (s, 1H, CONH), $\delta 8.38(\mathrm{~s}, 1 \mathrm{H}, \mathrm{CH}=\mathrm{N})$ and 9 aromatic protons as multiplets in the region of $\delta 7.39-8.40(\mathrm{~m}, 9 \mathrm{H}, \mathrm{ArH})$ Figure 4. In the ${ }^{1} \mathrm{H}$ NMR spectrum of $\mathrm{Zn}$ (II) complex showed the disappearance of signal due to protons of carboxylic acid and phenolic $\mathrm{OH}$ confirms the involvement of bonding to metal ion via deprotonation. The ${ }^{1} \mathrm{H}$ NMR of $\mathrm{Zn}$ (II) complex displayed three distinct singlet at $\delta$ 9.23(s, 1H, CONH), $\delta 8.38$ (s, 1H, CONH) and 8.20 $(\mathrm{s}, 1 \mathrm{H}, \mathrm{CH}=\mathrm{N})$ and 9 aromatic protons as multiplets in the region 7.07-8.10 (m,9H, ArH). When compared to the ${ }^{1} \mathrm{H}$ NMR spectrum of Schiff base ligand and its metal complex, it was found that the signals due to the amide $\mathrm{NH}, \mathrm{NH}$ attached to thiazole, azomethine proton and aromatic protons have been shifted towards down field strength confirming the complexation of $\mathrm{Zn}$ (II) ion with ligand. ${ }^{35}$ Figure 5.

\section{ESI- mass spectral studies}

The ESI mass spectra of the Schiff base ligand (L) and its $\mathrm{Cu}$ (II), and Co (II) complexes have been studied for their mass spectral studies. The ESI-mass spectra of the compounds exhibited molecular ion peaks equivalent to their molecular weight along other fragment peaks Figure 6. The ESI mass spectrum of the Schiff base ligand (L) showed a molecular ion peak recorded at $\mathrm{m} / \mathrm{z}$ 382 which is equivalent to its molecular weight. Similarly, the ESI mass spectra of $\mathrm{Cu}$ (II) and Co (II) complexes 


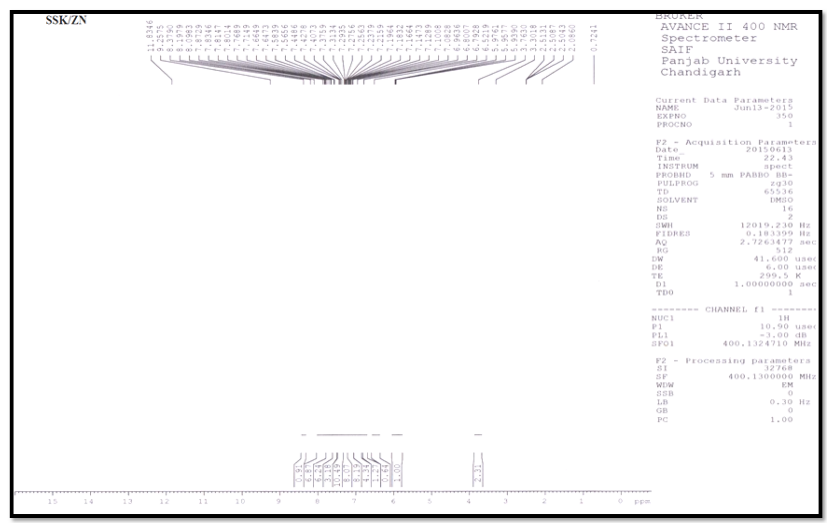

Figure 5: ${ }^{1}$ NMR spectrum of Zn (II) complex

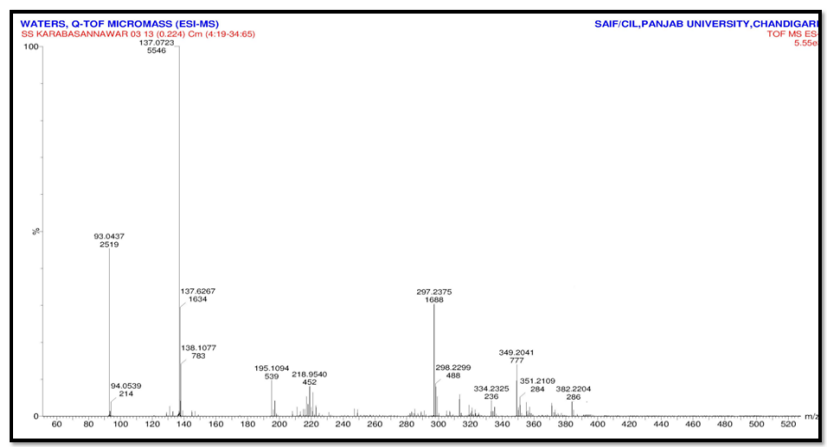

Figure 6: ESI Mass Spectrum of Schiff Base Ligand

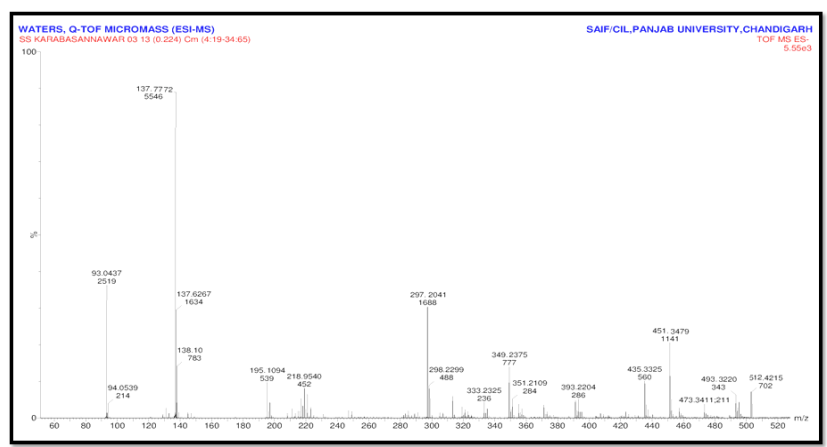

Figure 7: ESI Mass Spectrum of Cu (II) complex

showed a molecular ion peaks recorded to $\mathrm{m} / \mathrm{z} 512$ and 508 respectively which are equivalent to their molecular weights Figure 7.

\section{Biological Activities}

\section{In vitro antimicrobial activity}

The synthesized ligand and their metal complexes have been screened for their antimicrobial activity. The antimicrobial activities were carried out against Escherichia coli, Salmonella typhi, Bacillus subtilis and Staphylococcus aureus bacterial strains and anti fungal activity against Candida albicans, Cladosporium oxy-sporum and Aspergillus niger fun-

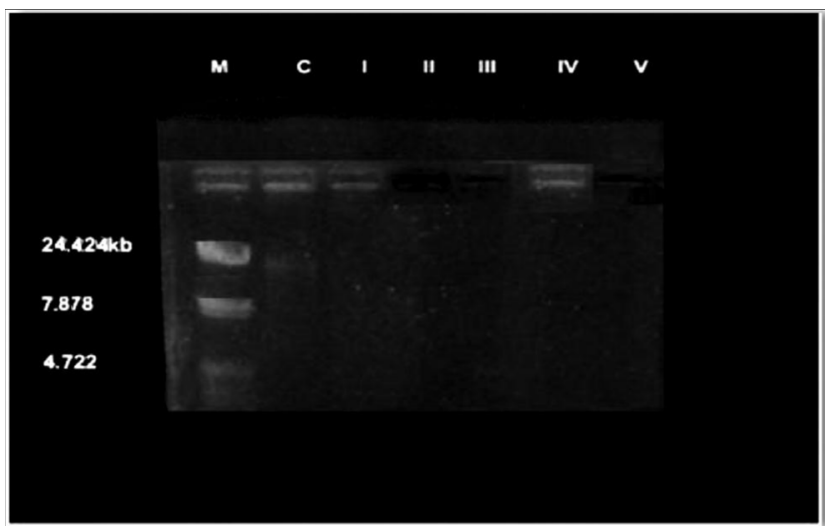

Figure 8: DNA cleavage of super coiled plasmid DNA pBR322. $\mathrm{M}$, standard molecular weight marker; $\mathrm{C}$, control. Ligand (Lane I) and its Cu (II), Co (II) and Ni (II) (Lane II, III and IV) were treated plasmid DNA pBR322 with respective compounds.

gal strains. The antimicrobial activity results and minimum inhibitory concentration values of the compounds against respective strains are summarized in Table 4 . the antimicrobial activity results of all the synthesized compounds exhibit antimicrobial properties and it is important to note that the metal complexes exhibited more inhibitory effect compared to their respective ligands and their metal chlorides. The enhanced antimicrobial activity of the complexes over the ligands and their metal chlorides can be explained on the basis of chelation theory. ${ }^{36,37}$ It is known theory chelation enhances the ligand to act as more powerful potent bacterial agents, thus killing more of the bacteria than the ligand. The enhancement in the activity may be rationalized on the basis that ligands mainly possess azomethine $(\mathrm{C}=\mathrm{N})$ bond. It has been suggested that the ligands with hetro donor atoms (nitrogen and oxygen) inhibit enzyme activity, since the enzymes which require these groups for their activity appear to be especially more susceptible to deactivation by metal ion on coordination. It is observed that, in a complex, the positive charge of the metal ion is partially shared with the ligand and there may $\pi$-electron delocalization over the whole chelating system. ${ }^{38}$ Thus the increase in the lipophilic character of the metal chelates and favors its permeation through the lipoid layer of the bacterial membranes and blocking of the metal binding sites in the enzymes of microorganisms. The factors namely solubility, conductivity and bond length between the metal ion and the ligand also increases the activity. The increase in the activity of metal complexes against the fungi is due to the formation of a hydrogen bond the azomethine nitrogen atom and active centers of the cell constituents, resulting in the interference with the normal cell process. 


\section{DNA cleavage activity}

The ligand and its $\mathrm{Cu}(\mathrm{II}), \mathrm{Co}(\mathrm{II}), \mathrm{Ni}(\mathrm{II})$ and $\mathrm{Zn}(\mathrm{II})$ complexes were studied for their DNA cleavage activity by agarose gel electrophoresis method against supercoiled DNA pBR 322 (Bangal re Genei, Bengaluru, Cat.No.105850) as a target molecule and the gel picture showing cleavage is depticted in Figure 8. The characterization of DNA recognition by transition metal complex has been aided by the DNA cleavage chemistry associated with redox active or photo- activated metal complexe. ${ }^{39}$ The electrophoresis analysis clearly revealed that the ligand and its metal complexes have acted on DNA because of a difference in molecular weight between the control and the treated DNA samples. The difference was observed in the bands of lanes of complexes compared with the control DNA (lane C) of pBR322 due to the relaxation of circu- lar DNA into linear form. This shows that the control DNA alone does not show any apparent cleavage, whereas the ligand and its metal complexes do show. In the present case, the ligand( Lane I) and its $\mathrm{Cu}$ (II), Co (II) and Ni (II) (Lane II, III and IV) complexes showed complete cleavage of supercoiled DNA whereas Zn (II) complex showed partial cleavage of supercoiled DNA. It can be concluded that all the compounds under present study inhibited the growth of pathogenic organisms by DNA cleavage as has been observed on the DNA cleavage of supercoiled plasmid DNA pBR322.

\section{In vitro Cytotoxicity}

The brine shrimp bioassay is an excellent tool to be used for monitoring the biological activity in order to predict the ability to kill cancer cells. ${ }^{40}$ A summary of the cytotoxic assay results of the Schiff base ligand (L)

\section{Table 1: Physical, Analytical and Molar conductance data of Schiff base ligand (L) and its metal complexes}

\begin{tabular}{|c|c|c|c|c|c|c|c|c|c|c|c|}
\hline \multirow{2}{*}{ Compounds } & \multirow{2}{*}{ M.W. ${ }^{a}$} & \multirow{2}{*}{$\begin{array}{l}\text { M.P } \\
\left({ }^{\circ} \mathrm{C}\right)^{b}\end{array}$} & & & \multicolumn{5}{|c|}{ Elemental analysis found [\%] } & \multirow{2}{*}{$\begin{array}{c}\lambda\left(\mathrm{cm}^{2} \Omega\right. \\
\left.{ }^{1} \mathrm{~mol}^{-1}\right)\end{array}$} & \multirow{2}{*}{ Color } \\
\hline & & & M & C & H & $\mathbf{N}$ & 0 & S & $\mathrm{Cl}$ & & \\
\hline $\mathrm{C}_{18} \mathrm{H}_{14} \mathrm{~N}_{4} \mathrm{O}_{4} \mathrm{~S}$ & 382.4 & $274-280$ & ----- & 56.54 & 3.69 & 14.65 & 16.74 & 8.39 & ----- & ----- & Yellow \\
\hline$\left[\mathrm{Cu}\left(\mathrm{C}_{18} \mathrm{H}_{12} \mathrm{~N}_{4} \mathrm{O}_{3} \mathrm{~S}\right) \mathrm{Cl}_{2}\right]$ & 498.8 & 286 & 12.74 & 43.34 & 2.42 & 11.23 & 9.62 & 6.43 & 14.21 & 24 & Green \\
\hline$\left[\mathrm{Co}\left(\mathrm{C}_{18} \mathrm{H}_{12} \mathrm{~N}_{4} \mathrm{O}_{3} \mathrm{~S}\right) \mathrm{Cl}_{2}\right]$ & 494.2 & 290 & 11.92 & 43.74 & 2.45 & 11.34 & 9.71 & 6.49 & 14.35 & 18 & Brown \\
\hline$\left[\mathrm{Ni}\left(\mathrm{C}_{18} \mathrm{H}_{12} \mathrm{~N}_{4} \mathrm{O}_{3} \mathrm{~S}\right) \mathrm{Cl}_{2}\right]$ & 494 & 285 & 11.34 & 43.77 & 2.45 & 11.34 & 9.72 & 6.49 & 14.35 & 36 & Brown \\
\hline$\left[\mathrm{Zn}\left(\mathrm{C}_{18} \mathrm{H}_{12} \mathrm{~N}_{4} \mathrm{O}_{3} \mathrm{~S}\right) \mathrm{Cl}_{2}\right]$ & 500.7 & 287 & 13.06 & 43.18 & 2.42 & 11.19 & 9.59 & 6.40 & 14.16 & 30 & $\begin{array}{l}\text { Pale } \\
\text { Yellow }\end{array}$ \\
\hline
\end{tabular}

a molecular weight of the compounds

${ }^{\mathrm{b}}$ melting point if the compounds at their decomposition

\begin{tabular}{|c|c|c|c|c|c|c|c|c|c|}
\hline Compounds & Amide NH & $\begin{array}{c}\text { Thiazole } \\
\text { NH }\end{array}$ & $\mathrm{C}=\mathrm{O}$ & $\mathrm{C}=\mathrm{N}$ & $\mathrm{OH}$ & $\mathrm{COOH}$ & M-O & $\mathbf{M}-\mathbf{N}$ & $\mathrm{M}-\mathrm{Cl}$ \\
\hline $\mathrm{C}_{18} \mathrm{H}_{14} \mathrm{~N}_{4} \mathrm{O}_{4} \mathrm{~S}$ & 3259 & 3119 & 1727 & 1628 & 3176 & 3480 & ---- & ---- & ---- \\
\hline$\left[\mathrm{Cu}\left(\mathrm{C}_{18} \mathrm{H}_{12} \mathrm{~N}_{4} \mathrm{O}_{3} \mathrm{~S}\right) \mathrm{Cl}_{2}\right]$ & 3229 & 3104 & 1726 & 1591 & ---- & ------ & 542 & 495 & 368 \\
\hline$\left[\mathrm{Co}\left(\mathrm{C}_{18} \mathrm{H}_{12} \mathrm{~N}_{4} \mathrm{O}_{3} \mathrm{~S}\right) \mathrm{Cl}_{2}\right]$ & 3221 & 3096 & 1727 & 1594 & ---- & ----- & 533 & 489 & 360 \\
\hline$\left[\mathrm{Ni}\left(\mathrm{C}_{18} \mathrm{H}_{12} \mathrm{~N}_{4} \mathrm{O}_{3} \mathrm{~S}\right) \mathrm{Cl}_{2}\right]$ & 3220 & 3096 & 1726 & 1593 & ---- & ----- & 536 & 497 & 337 \\
\hline$\left[\mathrm{Zn}\left(\mathrm{C}_{18} \mathrm{H}_{12} \mathrm{~N}_{4} \mathrm{O}_{3} \mathrm{~S}\right) \mathrm{Cl}_{2}\right]$ & 3225 & 3063 & 1726 & 1556 & ---- & ----- & 546 & 496 & 326 \\
\hline
\end{tabular}

\begin{tabular}{|c|c|}
\hline \multicolumn{2}{|c|}{ Table 3: ${ }^{1} \mathrm{HNMR}$ data of Schiff base ligand (L) and its Zn (II) metal complexes } \\
\hline Ligand / complex & ${ }^{1} \mathbf{H}$ NMR data (ppm) \\
\hline $\mathrm{C}_{18} \mathrm{H}_{14} \mathrm{~N}_{4} \mathrm{O}_{4} \mathrm{~S}$ & $13.59(\mathrm{~s}, 1 \mathrm{H}$, Carboxylic acid) \\
& $12.2(\mathrm{~s}, 1 \mathrm{H}$, Phenolic OH) \\
& $10.70(\mathrm{~s}, 1 \mathrm{H}, \mathrm{NH}$ attached to thiazole) \\
& $8.93(\mathrm{~s}, 1 \mathrm{H}, \mathrm{CONH})$ \\
& $8.38(\mathrm{~s}, 1 \mathrm{H}, \mathrm{CH}=\mathrm{N})$ \\
& $7.39-8.40(\mathrm{~m}, 9 \mathrm{H}, \mathrm{ArH})$. \\
\hline$\left[\mathrm{Zn}\left(\mathrm{C}_{18} \mathrm{H}_{12} \mathrm{~N}_{4} \mathrm{O}_{3} \mathrm{~S}\right) \mathrm{Cl}_{2}\right]$ & $9.23(\mathrm{~s}, 1 \mathrm{H}, \mathrm{NH}$ attached to thiazole $)$ \\
& $8.38(\mathrm{~s}, 1 \mathrm{H}, \mathrm{CONH})$ \\
& $8.20(\mathrm{~s}, 1 \mathrm{H}, \mathrm{CH}=\mathrm{N})$ \\
& $7.07-8.10(\mathrm{~m}, 9 \mathrm{H}, \mathrm{ArH})$ \\
\hline
\end{tabular}




\begin{tabular}{|c|c|c|c|c|c|c|c|}
\hline \multirow[t]{2}{*}{ Compounds } & \multicolumn{4}{|c|}{ Bacteria } & \multicolumn{3}{|c|}{ Fungi } \\
\hline & S.aureus & B.Subtilis & E.coli & S.typhi & C.albicans & C.oxysporum & A.niger \\
\hline $\mathrm{C}_{18} \mathrm{H}_{14} \mathrm{~N}_{4} \mathrm{O}_{4} \mathrm{~S}$ & 50 & 75 & 75 & 50 & 75 & 75 & 50 \\
\hline$\left[\mathrm{Cu}\left(\mathrm{C}_{18} \mathrm{H}_{12} \mathrm{~N}_{4} \mathrm{O}_{3} \mathrm{~S}\right) \mathrm{Cl}_{2}\right]$ & 50 & 25 & 50 & 25 & 50 & 25 & 50 \\
\hline$\left[\mathrm{Co}\left(\mathrm{C}_{18} \mathrm{H}_{12} \mathrm{~N}_{4} \mathrm{O}_{3} \mathrm{~S}\right) \mathrm{Cl}_{2}\right]$ & 25 & 50 & 25 & 50 & 25 & 50 & 25 \\
\hline$\left[\mathrm{Ni}\left(\mathrm{C}_{18} \mathrm{H}_{12} \mathrm{~N}_{4} \mathrm{O}_{3} \mathrm{~S}\right) \mathrm{Cl}_{2}\right]$ & 50 & 25 & 50 & 50 & 50 & 25 & 50 \\
\hline$\left[\mathrm{Zn}\left(\mathrm{C}_{18} \mathrm{H}_{12} \mathrm{~N}_{4} \mathrm{O}_{3} \mathrm{~S}\right) \mathrm{Cl}_{2}\right]$ & 50 & 50 & 50 & 50 & 25 & 50 & 25 \\
\hline Gentamicin & 12.50 & 12.50 & 12.50 & 12.50 & -- & -- & -- \\
\hline Fluconazole & -- & -- & -- & -- & 12.50 & 12.50 & 12.50 \\
\hline
\end{tabular}

\begin{tabular}{|c|c|}
\hline \multicolumn{2}{|c|}{ Table 5: Brine shrimp bioassay data of the Schiff base ligand (L) and its metal complexes } \\
\hline Compounds & LD50(M/mL) \\
\hline $\mathrm{C}_{18} \mathrm{H}_{14} \mathrm{~N}_{4} \mathrm{O}_{4} \mathrm{~S}$ & $2.276 \times 10^{-4}$ \\
\hline$\left[\mathrm{Cu}\left(\mathrm{C}_{18} \mathrm{H}_{12} \mathrm{~N}_{4} \mathrm{O}_{3} \mathrm{~S}\right) \mathrm{Cl}_{2}\right]$ & $2.187 \times 10^{-4}$ \\
\hline$\left[\mathrm{Co}\left(\mathrm{C}_{18} \mathrm{H}_{12} \mathrm{~N}_{4} \mathrm{O}_{3} \mathrm{~S}\right) \mathrm{Cl}_{2}\right]$ & $1.104 \times 10^{-4}$ \\
\hline$\left[\mathrm{Ni}\left(\mathrm{C}_{18} \mathrm{H}_{12} \mathrm{~N}_{4} \mathrm{O}_{3} \mathrm{~S}\right) \mathrm{Cl}_{2}\right]$ & $2.321 \times 10^{-4}$ \\
\hline$\left[\mathrm{Zn}\left(\mathrm{C}_{18} \mathrm{H}_{12} \mathrm{~N}_{4} \mathrm{O}_{3} \mathrm{~S}\right) \mathrm{Cl}_{2}\right]$ & $1.145 \times 10^{-4}$ \\
\hline
\end{tabular}

and its metal complexes is presented in Table 5. The standard anticancer drug bleomycin showed the $\mathrm{LD}_{50}$ value $0.51 \times 10^{-4}$. Among all the compounds tested Co (II) complex showed the highest cytotoxicity with $\mathrm{LD}_{50}$ value of $1.108 \times 10^{-4}$ which is indicative of its potent cytotoxicity than other coordination complexes in this experiment showed followed by $\mathrm{Zn}$ (II) complex with $\mathrm{LD}_{50}$ value of $1.156 \times 10^{-4}$. On the other hand, ligand (L), $\mathrm{Cu}$ (II) and Ni (II) complex were found to be inactive against A.salina.

\section{CONCLUSION}

The newly synthesized Schiff base ligand 2-hydroxy3-((4-(4-phenylthiazol-2-yl) semicarbazide) methyl) benzoic acid behaves as tridentate $\mathrm{OON}$ donor and the complexes of square pyramidal coordination type $\left[\mathrm{ML}(\mathrm{Cl})_{2}\right]$. The help of various physicochemical and spectroscopic methods such as IR, ${ }^{1} \mathrm{H}$ NMR, the square pyramidal coordination geometries of $\mathrm{Cu}$ (II), Co (II), Ni (II), and $\mathrm{Zn}$ (II) complexes have been proposed (scheme 2). The non-electrolyte nature of the complexes was confirmed on the basis of their molar conductance values. The newly synthesized metal complexes having good antimicrobial activity when compared to Schiff base ligand. The DNA cleavage activity of all the newly synthesized compounds showed the cleavage of plasmid DNA cleavage. In addition to that, cytotoxicity of $\mathrm{Co}$ (II) and $\mathrm{Zn}$ (II) complexes indicate potent cytotoxic agents that might become potent anticancer agent in clinical trials. Hence from all these extensive observations; it was concluded that the Schiff base ligand (L) and its metal complexes give the significant, adaptable and valuable information of coordination compounds and also they may be used as potent biological agents with reduced toxicity and higher efficiency.<smiles></smiles>

$\mathrm{M}=\mathrm{Cu}$ (II), $\mathrm{Co}$ (II), $\mathrm{Ni}$ (II), and $\mathrm{Zn}$ (II)

Scheme 2: Proposed structure of the complexes.

\section{ACKNOWLEDGMENT}

Authors are thankful to Principal, HOD Department of chemistry BLDE's science college Jamkhandi, Karnataka, India for providing necessary facilities for research. Authors are extended their thanks to professor, chairman of department chemistry and Coordinator of Research and development centre Bharathiar University Coimbatore. Authors are also thanks to SAIF Punjab University, Chandigarh, for providing FT-IR, ${ }^{1} \mathrm{H}$ NMR and ESI mass spectral data, and Biogenic Research and Training Centre in Biotechnology, Hubli, for Biological analysis. 


\section{CONFLICT OF INTEREST}

No conflict of interest are declared.

\section{ABBREVIATION USED}

FT-IR: Fourier Trans- form Infrared; ${ }^{1} \mathbf{H}$ NMR: Proton Nuclear Magnetic Resonance; ESI mass: Electrospray Ionization Mass Spectrometry; DNA: Deoxyribonucleic acid; TLC: Thin-layer chromatography; DMSO: Dimethyl sulfoxide; TMS: Tetramethylsilane; DMF: Dimethylformamide; MTCC: Microbial Type Culture Collection and Gene Bank; PDA: Potato dextrose agar; EDTA: Ethylene diamine tetraacetic acid; MIC: Minimum inhibitory concentration; LD50: Lethal Dose; ETBr: Ethidium bromide.

\section{REFERENCE}

1. Belaid S, Landreau A, Djebbar S, Benali-Baitich O, Bouet G, Bouchara JP. Synthesis, characterization and antifungal activity of a series of manganese (II) and copper (II) complexes with ligands derived from reduced N, N'Ophenylenebis (salicylideneimine). J Inorg Biochem. 2008;102:63e69.

2. Rabie UM, Assran ASA, Abou-EI-Wafa MHM. Unsymmetrical Schiff base functionalize as base bibasic tetradentate (ONNO) and monobasic trientate (NNO) ligands on complexation with some transition ions. J Mol Struct. 2008;872:113e122.

3. Yilmaz I, Temel $\mathrm{H}$, Synthesis $\mathrm{AH}$. Electrochemistry and insitu spectroelectrochemistry of a New Co (III) thio Schiff-base complex with N, N'Bis(2-aminothiophenol)-1,4-bis (carboxylidene phenoxy)butane. Polyhedron. 2008;27:125e132

4. Salavati M, e Niasari, Sobbani A. Ship-in-a-bottle synthesis, characterization and catalytic oxidation of cyclohexane by host (nanopores of zeolite-Y)/ guest ( $\mathrm{Mn}(\mathrm{II}), \mathrm{Co}(\mathrm{II}), \mathrm{Ni}(\mathrm{II})$ and $\mathrm{Cu}(\mathrm{II})$ complexes of bis(salicyaldehyde) oxaloyldihydrazone) nanocomposite materials. $\mathrm{J}$ Mol Catal (A). 2008;285:58e67.

5. Juan CL, Jie B, Ming MF, Xing LG. Oxidative carbonylation of aniline to N,NOdiphenyl urea catalyzed by cobalt (II)eSchiff base complex/pyridine catalytic system. Catal Commun. 2008;9:658.

6. Ziyadanogullari B, Cevizic D, Temel H, Gullari RZ. Synthesis, characterization and structure effects on preconcentration and extraction of $\mathrm{N}, \mathrm{N}$ '-bis(salicylaldehydene)-1,4-bis- ( $p$ - aminophenoxy) butane towards some divalent cations. J Hazard Mater. 2008;150:285e-9.

7. Refat MS, El-Sayed MY, Adam AMA. Cu(II), $\mathrm{Co}(\mathrm{II})$ and $\mathrm{Ni}(\mathrm{II})$ complexes of new Schiff base ligand: Synthesis, thermal and spectroscopic characterizations. Journal of Molecular Structure. 2013;1038:62-72. DOI: 10.1016/j.molstruc.2013.01.059

8. Nejo AA, Kolawole GA, Nejo AO. Synthesis, characterization, antibacterial, and thermal studies of unsymmetrical Schiff-base complexes of cobalt (II), Journal of Coordination Chemistry 63 (24), Journal of Coordination Chemistry. 2010;63(24):4398-410. http://dx.doi.org/10.1080/00958972.201 0.532871

9. Saadeh SM. "Synthesis, characterization and biological properties of $\mathrm{Co}(\mathrm{II})$, $\mathrm{Ni}(\mathrm{II}), \mathrm{Cu}(\mathrm{II})$ and $\mathrm{Zn}(\mathrm{II})$ complexes with an SNO functionalized ligand,". Arabian Journal of Chemistry. 2013;6(2):191-6. http://dx.doi.org/10.1016/j. arabjc.2010.10.002

10. Joshep J, Mehta BH. Synthesis, charasctrization, and thermal analysis of transition metal complexes of polydentate ONO donar Schiff base ligand. Russian Journal of Coordination Chemistry. 2007;33(2):124-9. doi:10.1134/ S1070328407020091

11. Santos MA, Sérgio M. Marques, Sílvia Chaves, Hydroxypyridinones as "privileged" chelating structures for the design of medicinal drugs. Coordination Chemistry Reviews. 2012;256(1-2):240-59. http://dx.doi. org/10.1016/j.ccr.2011.08.008

12. RajKM, Vivekanand B, Nagesh GY, Mruthyunjayaswamym BHM. Synthesis, spectroscopic characterization, electrochemistry and biological evaluation of some binuclear transition metal complexes of bicompartmental ONO donor ligands containing benzo[b]thiophene moiety, Journal of Molecular Structure. 2014;1059:280-93. http://dx.doi.org/10.1016/j.molstruc.2013.12.010

13. Crans DC, Woll KA, Prusinskas K, Johnson MD, Norkus E. Metal speciation in health and medicine represented by iron and vanadium. Inorg Chem. 2013;52:12262-75. doi: 10.1021/ic4007873

14. Rehman W, Saman F, Ahmad I. Synthesis, characterization, and biological study of some biologically potent schiff base transition metal complexes, Russian Journal of Coordination Chemistry. 2008;34(9):678-82. Doi: 10.1134/S107032840809008X

15. Choudharya A, Sharmaa R, Nagar M. Synthesis, characterization and antimicrobial activity of mixed ligand complexes of Co (II) and Cu (II) with $\mathrm{N}, \mathrm{O} / \mathrm{S}$ donor ligands and amino acids. International Research Journal of Pharmacy and Pharmacology. 2011;1(6):172-187.

16. Li Y, Xu Y, Qian X, Qu B. Tetrahedron Lett. 2004;45:1247-51.

17. Marcus Vinicius Nora de Souza, Synthesis and biological activity of natural thiazoles: An important class of heterocyclic compounds J. Sulfur Chem. 2005;26:429-49. http://dx.doi.org/10.1080/17415990500322792.

18. Singh HL, Sharma M, Varshney AK, "Studies on coordination compounds of organotin(IV) with schiff bases of amino acids," Synthesis and Reactivity in Inorganic and Metal-Organic Chemistry. 2000;30:445-56. http://dx.doi. org/10.1080/00945710009351773

19. Chohan ZH, Praveen M, Ghaffar A. Synthesis, characterization and biological role of anions (nitrate, sulfate, oxalate and acetate) in $\mathrm{Co}(\mathrm{II})$, $\mathrm{Cu}(\mathrm{II})$, and $\mathrm{Ni}(\mathrm{II})$ metal chelates of some Schiff base derived amino acids. Synth React Inor Met-Org Chem. 1998;28(10):1673-87. http://dx.doi. org/10.1080/00945719809349422

20. Fricker SP. Metal based drugs: from serendipity to design. Dalton Trans. 2007;43:4903-17.

21. Crichton RR, Dexter DT, Ward RJ. Molecular based neurodegenerative diseases, from molecular mechanisms to therapeutic strategies. Coord Chem Rev. 2008;252:1189-99.

22. Cini R, Tamasi G, Defazio S, Hursthouse MB. Unusual coordination behavior by three nonstriodal Anti-inflammatory drug from the oxicam family towards copper(II). Synthesis, X-ray structure for copper (II)- isoxicam, -meloxicam and-cinnoxicam derivatives complexes and cytotoxic activity for a copper (II)- piroxicam complex. J Inorg Biochem. 2007;101:1140-52.

23. Nag NK, Pal S, Singh C. Synth characterization cobalt(II), nickel(II), copper(II), palladium(II) dioxouranium(VI) complexes antipyrine Schiff base 3-formylsalicylic Acid. Transit Metal Chem. 2005;30:523-6.

24. Bottari B, Mascaras R, Monforte F, Ottana R, Rotondo E, Vigorita MG. Isoniazid-related copper(II) and nickel(II) complexes with antimycobacterial in vitro activity. Bio-Org Med Chem Lett. 200:657e-60.

25. Kapetanak SM, Zhao X, Yu S, Magliozzo-Johannes RS, Schelvis PM. Modification of the active site of Mycobacterium tuberculosisKatG after disruption of the MeteTyreTrp cross-linked adduct. J Inorg Biochem. 2007;101:422e-33.

26. Maccari R, Ottana R, Brune RB, Vigorita MG. In vitro advanced antimycobacterial screening of cobalt(II) and copper(II) complexes of fluorinated isonicotinoylhydrazones. Bioorg Med Chem Lett. 2004;14:5731e3

27. Mendham J, Denney RC, Barnes JD, Thomas MJK. Vogel's Quantitative Chemical Analysis, sixth ed., Prentice Hall, London, 2000.

28. Mruthyunjayaswamy BHM, Basavarajaiah SM, Indian J Chem Sec. 2009;48:1274-8.

29. Dholakiya PP, Patel MN. Metal complexes: Preparation, magnetic, spectral and biocidal studies of some mixed-ligand complexes with Schiff bases containing NO and NN donor atoms. Synth React Inorg Met-Org Chem. 2004;34:553-63.

30. Sambrook J, Fritsch EF, Maniatis T. Molecular Cloning, A Laboratory Manual, second ed., C old Spring Harbor, New York, 1989.

31. Meyer BN, Ferrigni NR, Putnam JE, Jacobsen LB, Nichols DE, McLaughlin JL. Planta Med. 1982;45:31-4.

32. Finney DJ, Probit Analysis, third ed., Cambridge University Press, United Kingdom, 1971.

33. Geary WJ, Coord. Chem Rev. 1971;7:81-122.

34. Rahaman F, ljare OB, Jadegoud Y, Mruthyunjayaswamy BHM. "Phenoxobridged symmetrical homobinuclear complexes derived from an "endoff" compartmental ligand, 2,6-bis[5-chloro-3-phenyl-1H-indole-2- 
carboxamidyliminomethyl]-4-methylphenol,". Journal of Coordination Chemistry. 2009;62(9):1457-67.

35. Alam MM, Begum R, Rahman SMM, Islam SMS. J Sci Res. 2011;3:609-17.

36. Sharma AK, Chandra S. "Complexation of nitrogen and sulphur donor Schiff 's base ligand to $\mathrm{Cr}(\mathrm{III})$ and $\mathrm{Ni}(\mathrm{II})$ metal ions: synthesis, spectroscopic and antipathogenic studies,". Spectrochimica Acta A. 2011;78(1):337-42.

37. Chohan ZH, Arif M, Akhtar MA, Supuran CT. "Metalbased antibacterial and antifungal agents: synthesis, characterization, and in vitro biological evaluation of $\mathrm{Co}(\mathrm{II}), \mathrm{Cu}(\mathrm{II}), \mathrm{Ni}(\mathrm{II})$, and $\mathrm{Zn}(\mathrm{II})$ complexes with amino acid-derived compounds,". Bioinorganic Chemistry and Applications. 2006, Article ID 83131, 13 pages, 2006.
38. El-Wahab ZHA, Mashaly MM, Salman AA, El-Shetary BA, Faheim AA. "Co(II), $\mathrm{Ce}(\mathrm{III})$ and $\mathrm{UO} 2(\mathrm{VI})$ bissalicylatothiosemicarbazide complexes: binary and ternary complexes, thermal studies and antimicrobial activity,". Spectrochimica Acta A. 2004;60(12):2861-73.

39. Sitlani A, Long EC, Pyle AM, Barton JK. "DNA photocleavage by phenanthrenequinone diimine complexes of rhodium(III): shape-selective recognition and reaction,". Journal of the American Chemical Society. 1992;114(7):2303-12.

40. Hartl M, Humpf HU. Toxicity Assessment of Fumonisins Using the Brine Shrimp (Artemia salina) Bioassay. Food Chem Tox. 2000;38:1097-102.

\begin{abstract}
PICTORIAL ABSTRACT

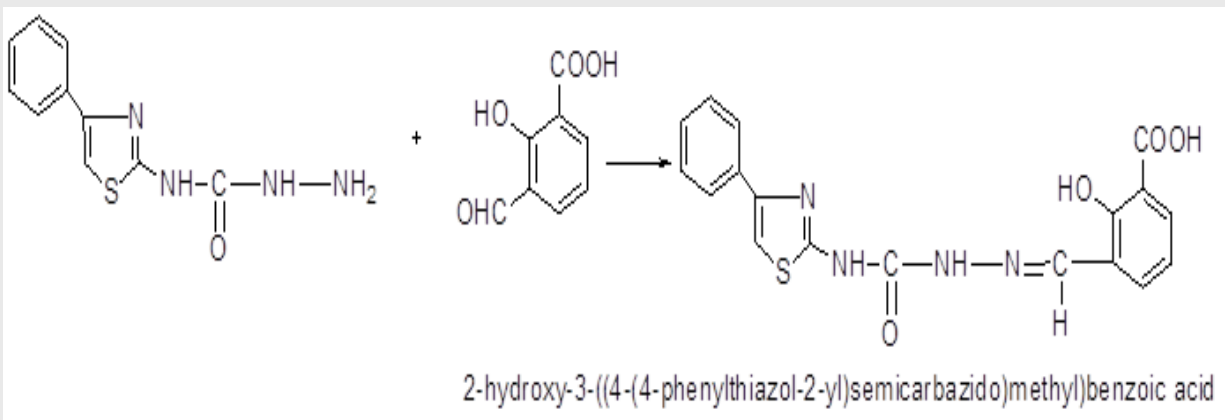

\section{SUMMARY}

- The newly synthesized Schiff base ligand 2-hydroxy-3-((4-(4-phenylthiazol-2-yl) semicarbazide) methyl) benzoic acid behaves as tridentate OON donor and the complexes of square pyramidal coordination type [ML (CI)2]. The help of various physicochemical and spectroscopic methods such as IR, ${ }^{1} \mathrm{H} N M R$, the square pyramidal coordination geometries of $\mathrm{Cu}$ (II), Co (II), Ni (II), and Zn (II) complexes have been proposed. The non-electrolyte nature of the complexes was confirmed on the basis of their molar conductance values. The newly synthesized metal complexes having good antimicrobial activity when compared to Schiff base ligand. The DNA cleavage activity of all the newly synthesized compounds showed the cleavage of plasmid DNA cleavage. In addition to that, cytotoxicity of Co (II) and Zn (II) complexes indicate potent cytotoxic agents that might become potent anticancer agent in clinical trials. Hence from all these extensive observations; it was concluded that the Schiff base ligand (L) and its metal complexes give the significant, adaptable and valuable information of coordination compounds and also they may be used as potent biological agents with reduced toxicity and higher efficiency
\end{abstract}

\title{
About Authors
}

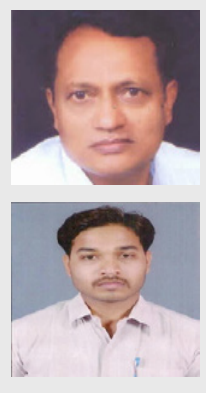

Dr. Basavaraj M. Kalshetty: Working as Associate Professor and Head of Department of Chemistry, BLDE's Science College Jamkhandi. Bagalkot District, Karnataka State, India. He has number research publication in national and international journals.

Shambuling Karabasannavar: Working as Assistant Professor and Head of Department of Chemistry, Biluru Gurubasava Mahaswamiji Institute of Technology, Mudhol, Bagalkot District, Karnataka State, India. He has 5 paper publications in international journals. Currently, he is pursuing PhD in Bharathiar University, Coimbatore, Tamilnadu, India.

Cite this article: Karabasannavar SS, Allolli PR, Kalshetty BM. Synthesis, Characterization, Antimicrobial, DNA cleavage, and Cytotoxicity Studies of Some Metal (II) Complexes of tridentate Schiff Base Ligand: 2-hydroxy-3((4-(4-phenylthiazol-2-yl) semicarbazide) methyl) benzoic acid. Indian J of Pharmaceutical Education and Research. 2017;51(4):748-57. 